\title{
Brown Marmorated Stink Bug, Halyomorpha halys (Stål) (Insecta: Hemiptera: Pentatomidae) ${ }^{1}$
}

\author{
Cory Penca and Amanda Hodges ${ }^{2}$
}

\section{Introduction}

The brown marmorated stink bug (BMSB), Halyomorpha halys (Stål) (Figure 1), is an invasive stink bug first identified in the United States near Allentown, Pennsylvania, in 2001, though it was likely present in the area several years prior to its discovery (Hoebeke and Carter 2003). In the United States, the brown marmorated stink bug has emerged as a major pest of tree fruits and vegetables, causing millions of dollars' worth of crop damage and control costs each year (Leskey et al. 2012a). The brown marmorated stink bug has also become a nuisance to homeowners due to its use of structures as overwintering sites (Inkley 2012). The significance of the brown marmorated stink bug has resulted in a large body of academic, government, and private sector research focused on its control.

\section{Synonymy}

Pentatoma halys Stål (1855)

Poecilometis mistus Uhler (1860)

Dalpada brevis Walker (1867)

Dalpada remota Walker (1867)

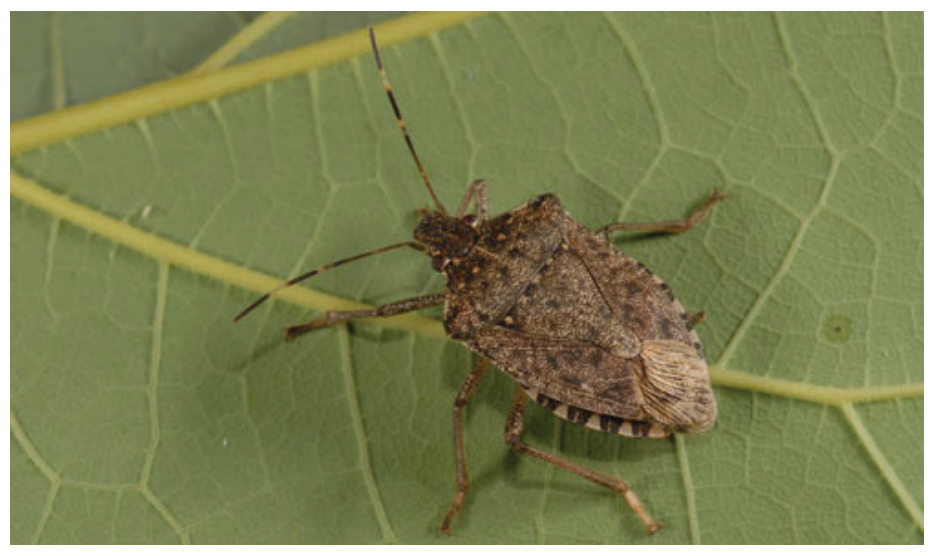

Figure 1. An adult brown marmorated stink bug, Halyomorpha halys (Stål).

Credits: Lyle J. Buss, UF/IFAS

\section{Distribution}

The brown marmorated stink bug is native to eastern Asia, including China, Taiwan, Korea, and Japan (Lee et al. 2013). Since its discovery in North America the brown marmorated stink bug has spread rapidly throughout the eastern and midwestern United States, as well as establishing on the West Coast (Figure 2). Following its invasion of North America, the brown marmorated stink bug has expanded its global range into Europe, Eurasia, and South America (Chile), making it an invasive species with a global impact (Wermelinger et al. 2008, Faúndez and Rider 2017, Valentin et al. 2017). The brown marmorated stink bug's association with human-made structures has made it an

1. This document is EENY346, one of a series of the Department of Entomology and Nematology, UF/IFAS Extension. Original publication date April 2005. Revised July 2010 and January 2019. Visit the EDIS website at https://edis.ifas.ufl.edu for the currently supported version of this publication. This document is also available on the Featured Creatures website at http://entomology.ifas.ufl.edu/creatures.

2. Cory Penca; and Amanda Hodges, associate Extension Scientist, Department of Entomology and Nematology; UF/IFAS Extension, Gainesville, FL 32611.

The Institute of Food and Agricultural Sciences (IFAS) is an Equal Opportunity Institution authorized to provide research, educational information and other services

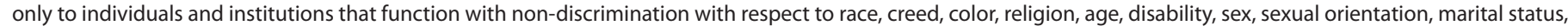

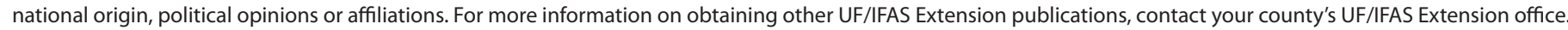
U.S. Department of Agriculture, UF/IFAS Extension Service, University of Florida, IFAS, Florida A \& M University Cooperative Extension Program, and Boards of County Commissioners Cooperating. Nick T. Place, dean for UF/IFAS Extension. 
adept hitchhiker; parked vehicles, including recreational vehicles and cargo containers, can serve as desirable overwintering sites for the brown marmorated stink bug. Subsequent movement of these vehicles and cargo across state lines or between countries has been implicated in its rapid spread. Although widespread in the United States, the brown marmorated stink bug has not established sustained reproducing populations in every state where detection has occurred. The invasive potential of the brown marmorated stink bug has led to increased vigilance on the part of nations that have not been invaded by the brown marmorated stink bug. Precautions to limit its global spread include inspections of potential host plants and the fumigation or heat treatment of cargo that may contain hitchhiking brown marmorated stink bugs (Duthie et al. 2012).

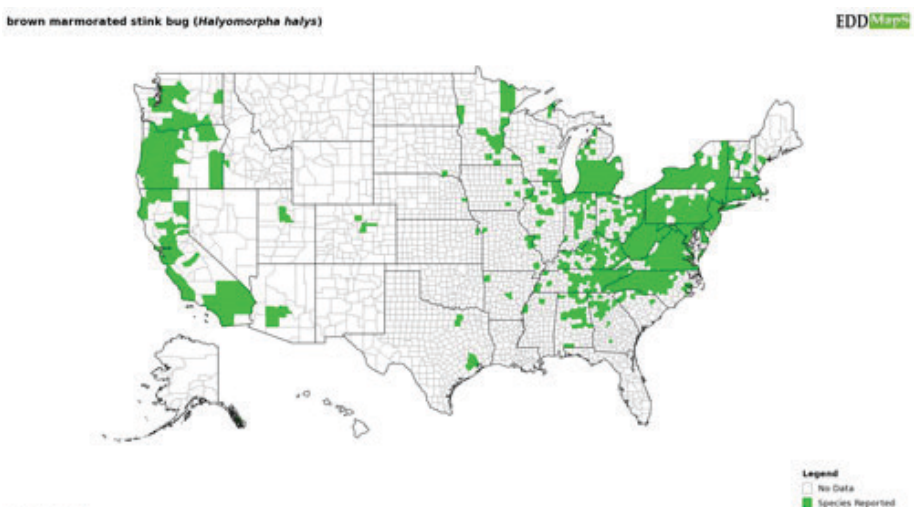

Figure 2. Distribution of the brown marmorated stink bug, Halyomorpha halys (Stål), in the United States based on reports submitted to Eddmaps.org, hosted by the University of GeorgiaCenter for Invasive Species and Ecosystem Health.

Credits: Gary Bernon, USDA-APHIS

\section{Description}

\section{Eggs}

The eggs of the brown marmorated stink bug are a light green or light blue color, $1 \mathrm{~mm}$ in diameter, and are laid in clutches of approximately 28 eggs (Figure 3). Eggs are usually located on the underside of leaves of host plants. As the embryo develops, it may become visible through the egg, with the eyes appearing as two red spots.

\section{Nymphs}

The first instar nymphs are approximately $2.4 \mathrm{~mm}$ in length, with a black head and thorax and an orange-red abdomen (Figure 4). Following the transition to second instar, the nymphs lose a majority of their orange-red coloring. Second instar nymphs appear dark with rough spiny projections along the lateral edge of the thorax. Wing buds begin to develop with each successive molt. Later instars have a black-to-gray base coloration with noticeable spines along the humeral margins as well as white bands on the legs and antennae (Figure 5). Nymphs of the rough stink bugs, Brochymena spp., may be confused with the brown marmorated stink bug nymphs due to the presence of spiny projections on the humeral margins and stripes on the legs; however, Brochymena nymphs lack the well-defined white stripes on the antennae (Figure 6).

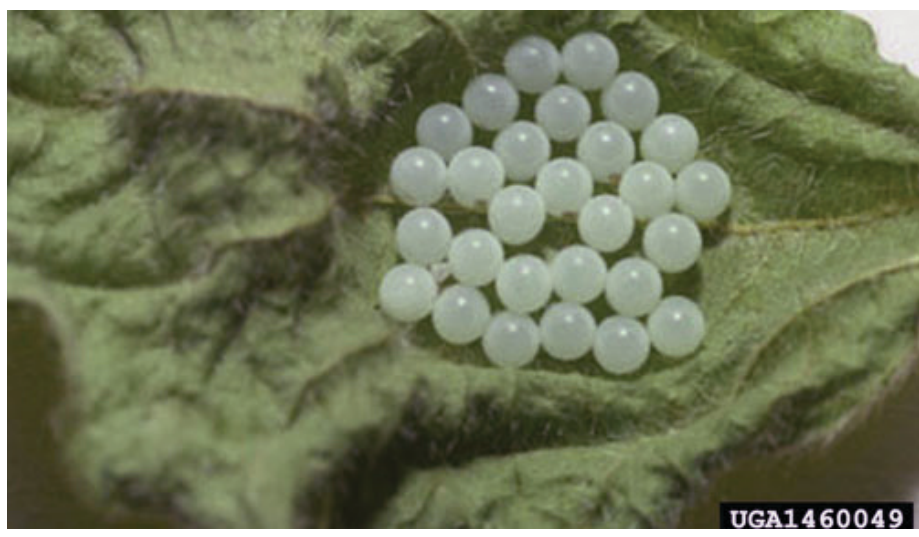

Figure 3. Eggs of the brown marmorated stink bug, Halyomorpha halys (Stål).

Credits: David R. Lance, USDA APHIS PPQ, Bugwood.org

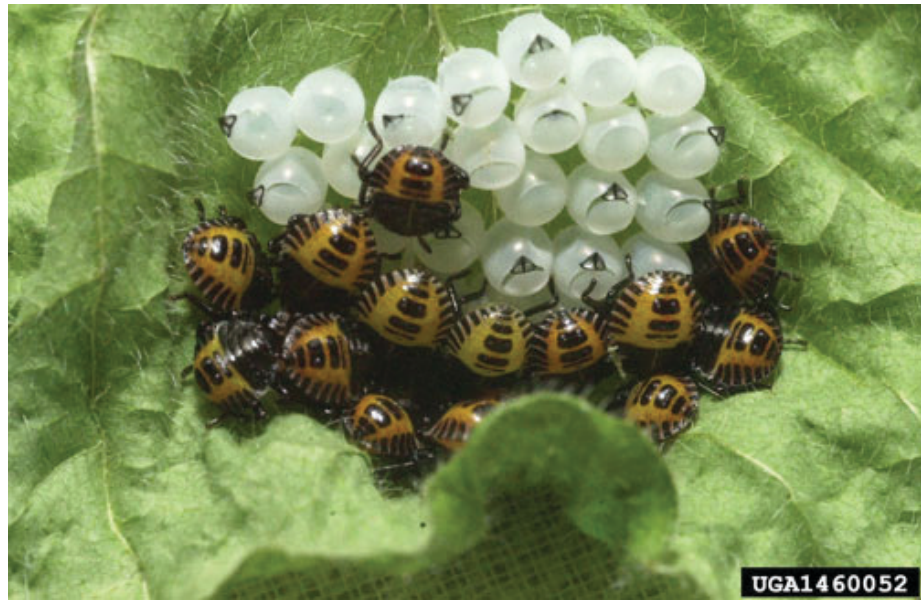

Figure 4. Recently hatched nymphs of the brown marmorated stink bug, Halyomorpha halys (Stål), aggregated near their egg clutch. Credits: David R. Lance, USDA APHIS PPQ, Bugwood.org

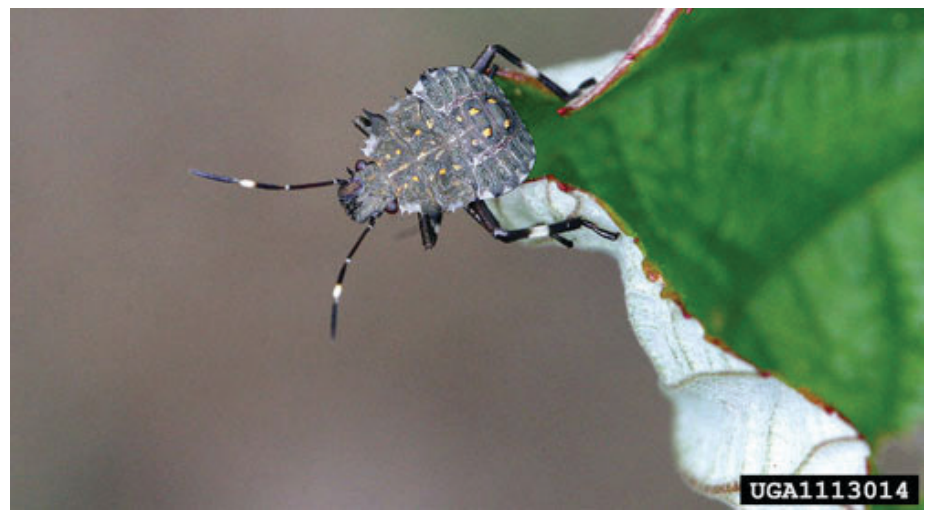

Figure 5. Late instar nymph of the brown marmorated stink bug, Halyomorpha halys (Stål).

Credits: Gary Bernon, USDA APHIS, Bugwood.org 


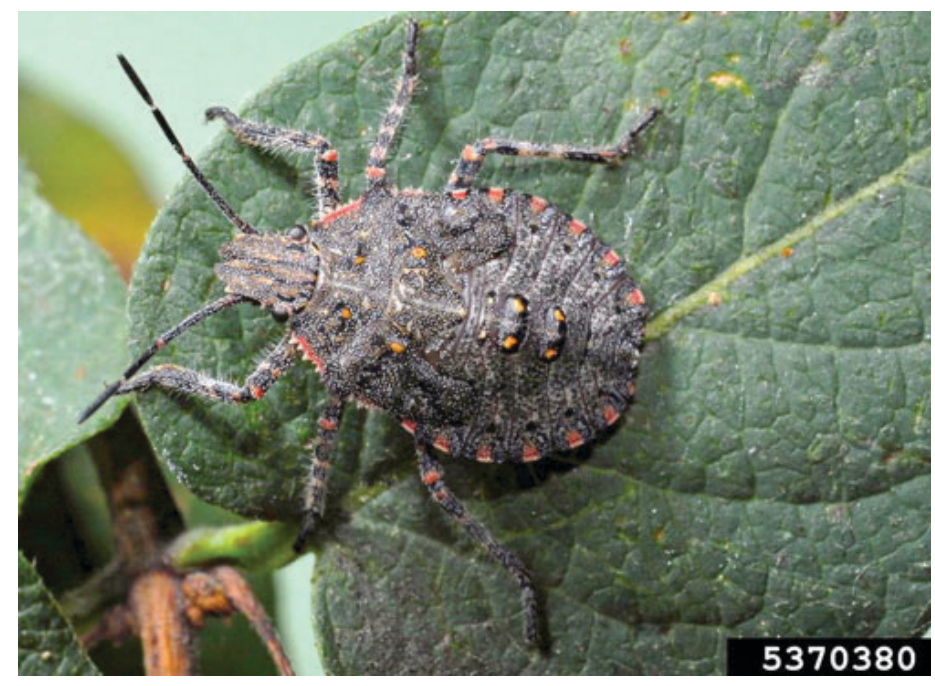

Figure 6. Late instar nymph from the genus Brochymena. Nymphs from this genus may be mistaken for the brown marmorated stink bug, Halyomorpha halys (Stål), nymphs due to the presence of spines on the humeral margins. They can be differentiated from the brown marmorated stink bug nymphs by the absence of clearly defined white stripes on the antennae.

Credits: Joseph Berger, Bugwood.org

\section{Adults}

Adults of the brown marmorated stink bug are larger than those of most native stink bug species, ranging from 12 to $17 \mathrm{~mm}$ in length. The base color is a mixture of brown, dark red, and black on the dorsal surface, with a beige or creamcolored ventral surface punctuated with metallic green markings on the ventral thorax. Key features for identification of the adult include white bands on antennae and legs, no humeral (shoulder) spines, and alternating dark and light bands on the margin of the abdomen (Figure 7).

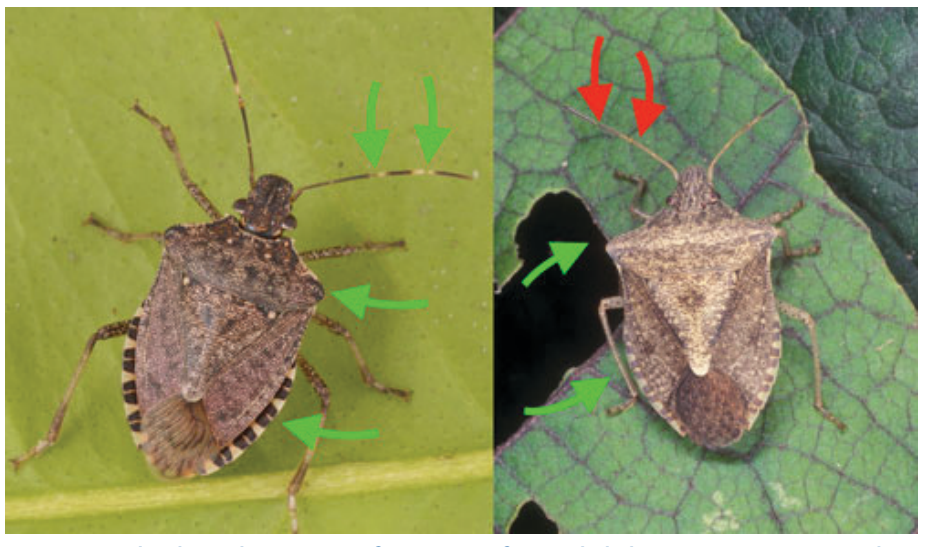

Figure 7. The key diagnostic features of an adult brown marmorated stink bug, Halyomorpha halys (Stål) (left). Green arrows indicate the banding of the antennae, rounded shoulders and alternating coloration on the margins of the abdomen. A similar stink bug species, Euschistus servus (Say) (right), has alternating coloration on the margins of the abdomen as well as rounded shoulders, but lacks the light bands on the antennae (red arrows).

Credits: Lyle J. Buss, UF/IFAS

\section{Life Cycle}

The brown marmorated stink bug, like all stink bugs, is a hemimetabolous insect. Development from egg to adult takes approximately 40 to 60 days, depending on temperature and photoperiod. After hatching, first instar nymphs may aggregate around the egg clutch before molting and dispersing to feed. Adults can produce multiple egg clutches throughout their lifespan. Winter diapause is a crucial component of the brown marmorated stink bug life cycle. Brown marmorated stink bugs respond to shortening daylength during fall by entering into diapause. During this period adult reproductive activity ceases as the stink bugs conserve resources to survive the winter. Only adults enter diapause and survive through the winter. Increased temperatures and daylength in the spring signal an end to the dormant period, and adult brown marmorated stink bugs will leave their overwintering sites in search of food. In warmer climates several generations per year are possible, though in most of its North American range the brown marmorated stink bug has one to two generations per year.

\section{Economic Importance}

As a polyphagous pest, the brown marmorated stink bug has the potential to cause damage to several crops, including tree fruit, nuts, vegetables and row crops. During outbreak years, the brown marmorated stink bug has caused significant losses to tree fruit producers, damaging apples, peaches, and pears. In 2010 the brown marmorated stink bug outbreak was the cause of over 37 million USD in losses to tree fruit producers in the mid-Atlantic region (Leskey et al. 2012b). In the western United States, the brown marmorated stink bug has been observed feeding on hazelnuts and almonds, two high-value nut crops. Vegetable producers have experienced economic damage, with feeding reported on sweet corn, beans, and tomatoes (Kuhar et al. 2012). Row crops such as field corn and soybean have also been affected by the brown marmorated stink bug, with damage occurring near field margins adjacent to wooded areas that serve as habitat for brown marmorated stink bug populations.

The appearance of crop injury varies depending on crop type. Feeding on tree fruit, nuts, and some vegetables can lead to corky spots in the flesh directly below the feeding site. Feeding can also cause discoloration, necrosis, or chlorotic spots due to tissue damage (Leskey and Nielsen 2018). Feeding on developing fruit, particularly peaches, can cause cat facing damage, in which the growing fruit fails to expand at the site of feeding injury, resulting in a malformed fruit (Figure 8). In most cases feeding by nymph and adult stages renders the fruit unmarketable. 


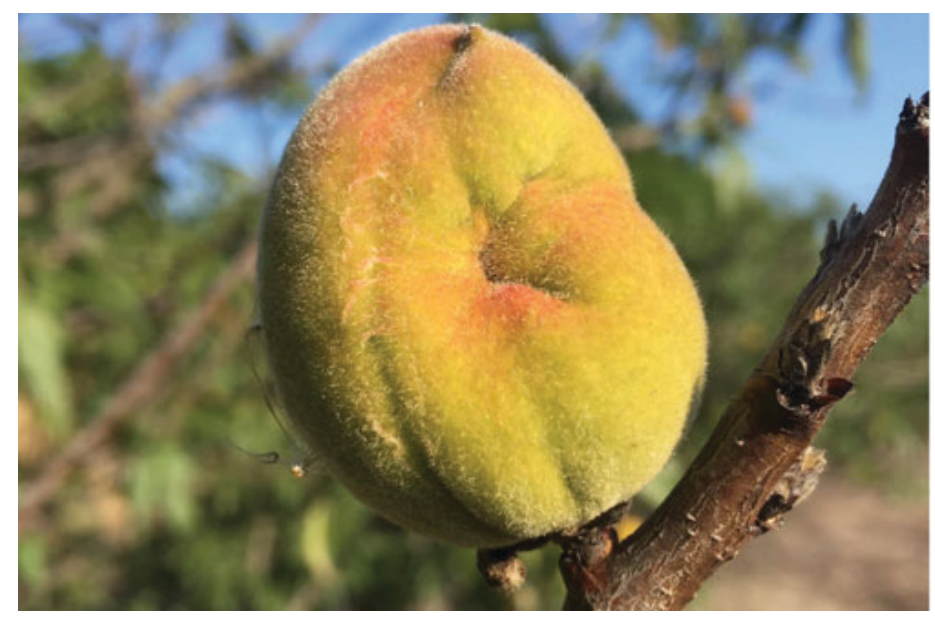

Figure 8. Cat facing injury to a developing peach fruit. This injury is typical of stink bug feeding, such as that caused by the brown marmorated stink bug, Halyomorpha halys (Stål). Other stink bugs in Florida, such as Euschistus servus (Say) and the leaffooted bug, Leptoglossus phyllopus (L.) can cause cat facing injury. Credits: Cory Penca, UF/IFAS

In addition to the economic losses from direct crop damage and increased control costs, the spread of the brown marmorated stink bug has severely disrupted established IPM programs, leading to increased use of broad-spectrum pesticides. While the careful and judicious use of pesticides has a high degree of safety, negative impacts to the environment and a reduction in populations of natural enemies in agricultural areas are associated with their use. The indirect costs associated with increased pesticide use following the establishment of the brown marmorated stink bug are difficult to measure but are undoubtedly significant.

The brown marmorated stink bug is also economically important as a nuisance pest, entering homes and other structures during the fall in search of a cool, dry place to overwinter. Homes near areas of high brown marmorated stink bug abundance can experience disturbingly high numbers of invading brown marmorated stink bugs. A study by Inkley (2012) collected 26,205 adult brown marmorated stink bugs in a single home over a 181-day period. While the presence of the brown marmorated stink bug poses no risk of harm to homeowners, crushing or otherwise agitating stink bugs will result in the release of an unpleasant odor, and their excrement may stain surfaces.

\section{Host}

Although the brown marmorated stink bug has been reported on several hundred host plants, it exhibits strong preferences for certain species, and prefers plants with fruiting structures. Crop hosts include apple, pear, peach, grape, blueberry, soybean, tomato, and corn. Several ornamental and landscape plants are also used by the brown marmorated stink bug, including princess tree (Paulownia), maple, and ash. While feeding is observed most commonly on fruiting structures of plants, the brown marmorated stink bug is capable of feeding on vegetative structures and can pierce through the bark of some trees to feed.

\section{Management}

\section{Agricultural}

Management of the brown marmorated stink bug in agricultural settings has primarily relied on the use of broad-spectrum insecticides. Excessive chemical control has interrupted established IPM programs for several crops (Blaauw et al. 2015). Because the pesticides that are most effective against the brown marmorated stink bug are often toxic to natural enemies, pollinators, and other beneficial insects, strategies to reduce the amount of pesticides used for control have been developed. Among these is the use of border sprays, which take advantage of the increased pest densities observed on border rows of crops, especially when borders are adjacent to forested areas.

Growers achieve equivalent control by directing the pesticide sprays to areas where pest populations are highest and reducing the amount of pesticides used in areas where pest density is lower. The discovery of the aggregation pheromone has allowed researchers to design lures which attract the brown marmorated stink bug to the vicinity of the lure location. When combined with traps, including black pyramid traps (Figure 9) and sticky traps, the lures can allow growers to determine when stink bug populations are at levels that warrant pesticide applications (Aldrich et al. 2009). Additionally, an attract-and-kill approach is under development, which aims to use the pheromone lure to attract stink bugs to specific trees which are then sprayed with pesticides (Morrison et al. 2016).

\section{Urban/Residential}

In residential settings the primary means of reducing home invasion by the brown marmorated stink bug is to seal entrances to the home, including repairing insect screening and sealing cracks and other building openings. Various traps have been designed for home use, with varying levels of success.

\section{Biological Control}

Native natural enemies have not been effective at controlling populations of the brown marmorated stink bug in its invasive range. Predators have been observed feeding on the brown marmorated stink bug, however, low rates of control have been reported, generally below $20 \%$. In its native range the brown marmorated stink bug experiences upwards 
of $70 \%$ parasitism from a number of hymenopteran egg parasitoids, however the parasitism rate for native egg parasitoids in the eastern United States is significantly lower, often below 10\% (Ogburn et al. 2016).

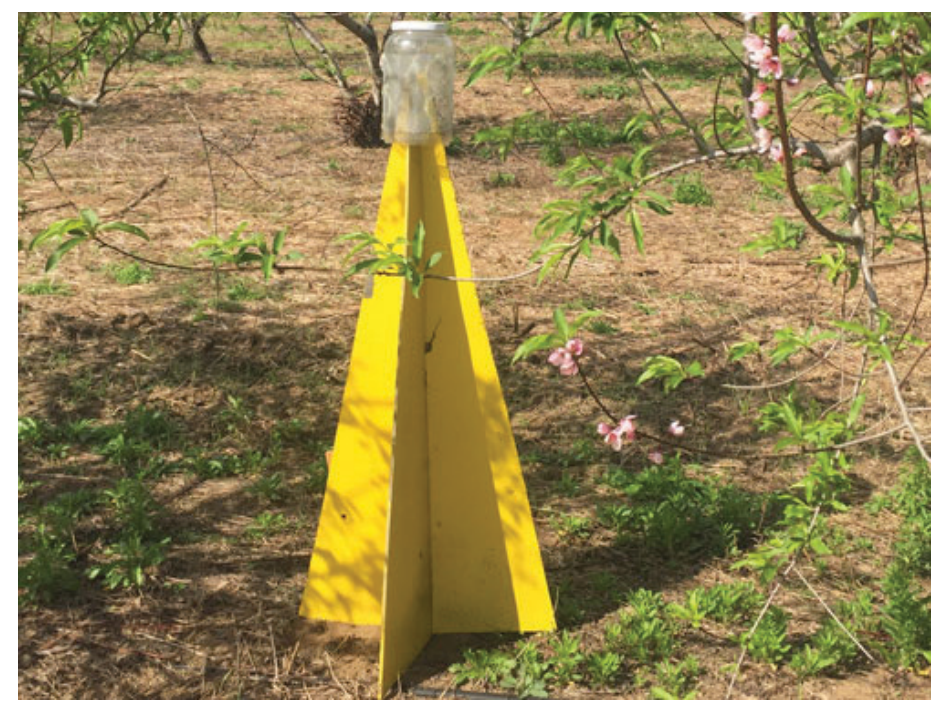

Figure 9. A pyramid trap used to monitor stink bugs in a peach orchard. A pheromone lure attractive to the brown marmorated stink bug, Halyomorpha halys (Stål), is placed inside the trap top to increase trap capture. A black trap is most commonly used for the brown marmorated stink bug.

Credits: Cory Penca, UF/IFAS

The samurai wasp, Trissolcus japonicus (Ashmead), has been identified as a potential classical biological control agent of the brown marmorated stink bug (Figure 10). In eastern Asia, the samurai wasp was observed parasitizing the eggs of the brown marmorated stink bug, with rates of parasitism averaging around 50\% throughout the year, with a peak of approximately $80 \%$ (Yang et al. 2009). The samurai wasp was imported into the United States and held in quarantine while being tested for efficacy and host specificity. Research suggests that the samurai wasp prefers the eggs of the brown marmorated stink bug and is unlikely to pose a threat to native stink bugs in the United States.

During the summer of 2015, the samurai wasp was discovered in the wild in Maryland (Talamas et al. 2015). The presence of the samurai wasp in North America is hypothesized to be an accidental introduction, possibly through the movement of parasitized eggs on cargo from eastern Asia. The duration of the established population of the samurai wasp in the United States is unknown. A second and distinct population of the samurai wasp was detected in Washington State, indicating the distribution of this species may be wider than previously considered (Milnes et al. 2016). The samurai wasp has been approved by the USDA for release in states where it has already been established. It is hoped that the widespread establishment of this biological control agent will reduce populations of the brown marmorated stink bug to an acceptable level.

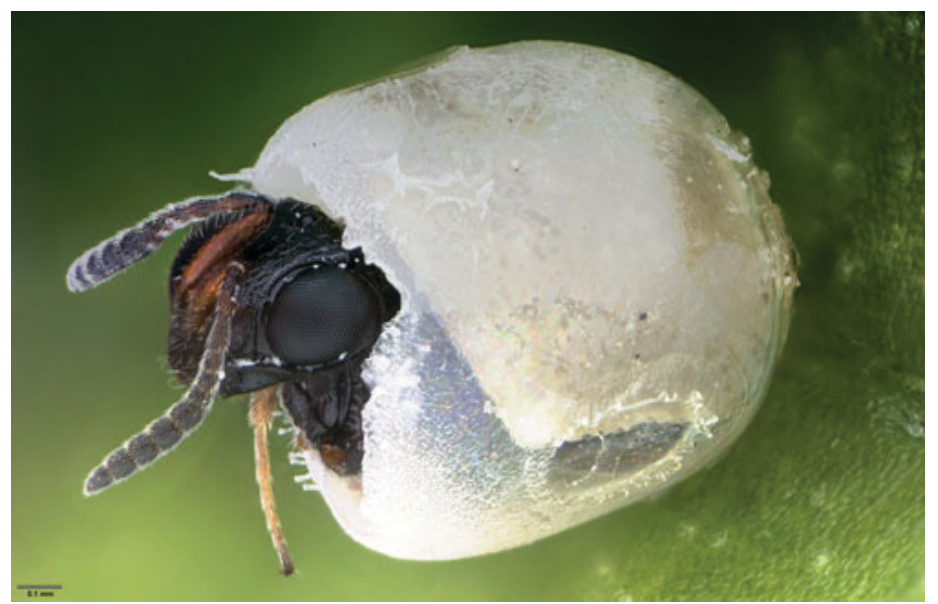

Figure 10. The samurai wasp, Trissolcus japonicus (Ashmead), an egg parasitoid of the brown marmorated stink bug, Halyomorpha halys (Stål), emerging from a stink bug egg. The samurai wasp has been approved for release as a biological control agent in some areas. Credits: Elijah Talamas, FDACS

\section{Brown Marmorated Stink Bugs in Florida}

While the brown marmorated stink bug is widespread and abundant in much of the United States, its movement into the Southeast has been relatively slow. Established, reproducing populations are reported in Georgia, but larger population outbreaks have not been observed. There have been multiple reports of the brown marmorated stink bug in Florida since 2006, but most reports have involved single specimens that were likely introduced as hitchhikers from northern states. In 2018 a survey of stink bug pests in Florida peaches detected nymphs and eggs of the brown marmorated stink bug from an orchard in Lake County, suggesting that a reproducing population of the brown marmorated stink bug may be established near this peach orchard (Penca and Hodges 2018). To date, the localized population in Lake County is the only confirmed established population of the brown marmorated stink bug in Florida. It remains to be seen if this population will persist and expand, or if it will become naturally extirpated.

\section{Acknowledgments}

The authors would like to thank Elijah Talamas, Susan Halbert, and Paul Skelley of the Florida Department of Agriculture and Consumer Services as well as Juanita Popenoe (UF/IFAS Lake Extension County) for reviewing this document and offering helpful suggestions. 


\section{Selected References}

Aldrich JR, Khrimian A, Chen X, Camp MJ. 2009.

"Semiochemically based monitoring of the invasion of the brown marmorated stink bug and unexpected attraction of the native green stink bug (Heteroptera: Pentatomidae) in Maryland." Florida Entomologist 92: 483-491.

Blaauw BR, Polk D, Nielsen AL. 2015. "IPM-CPR for peaches: Incorporating behaviorally-based methods to manage Halyomorpha halys and key pests in peach." Pest Management Science 71: 1513-1522.

Duthie C, Michael T, Stephenson B, Yamoah E, McDonald B. 2012. Risk Analysis of Halyomorpha halys (Brown Marmorated Stink Bug) on all pathways. Ministry of Primary Industries, Wellington, NZ. 57 p.

Faúndez EI, Rider D. 2017. "The brown marmorated stink bug Halyomorpha halys (Stål, 1855) (Heteroptera: Pentatomidae) in Chile." Arquivos Entomolóxicos 17: 305-307.

Hoebeke ER, Carter ME. 2003. “Halyomorpha halys (Stål) (Heteroptera: Pentatomidae): A polyphagous plant pest from Asia newly detected in North America." Proceedings of the Entomological Society of Washington 105: 225-237.

Inkley DB. 2012. "Characteristics of home invasion by the brown marmorated stink bug (Hemiptera: Pentatomidae)." Journal of Entomological Science 47: 125-130.

Kuhar TP, Kamminga KL, Tech V, Whalen J. 2012. The pest potential of brown marmorated stink bug on vegetable crops. Plant Management Network (19 October 2018)

Lee D-H, Short BD, Joseph S V., Bergh JC, Leskey TC. 2013. "Review of the biology, ecology, and management of Halyomorpha halys (Hemiptera: Pentatomidae) in China, Japan, and the Republic of Korea." Environmental Entomology 42: 627-641.

Leskey TC, Nielsen AL. 2018. "Impact of the invasive brown marmorated stink bug in North America and Europe: History, biology, ecology, and management." Annual Review of Entomology 63: 599-618.
Leskey TC, Hamilton GC, Nielsen AL, Polk DF, RodriguezSaona C, Christopher Bergh J, Herbert AD, Kuhar TP, Pfeiffer D, Dively GP, Hooks CRR, Raupp MJ, Shrewsbury PM, Krawczyk G, Shearer PW, Whalen J, Koplinka-Loehr C, Myers E, Inkley D, Hoelmer KA, Lee DH, Wright SE. 2012a. "Pest status of the brown marmorated stink bug, Halyomorpha halys in the USA." Outlooks on Pest Management 23: 218-226.

Leskey TC, Short BD, Butler BR, Wright SE. 2012b. "Impact of the invasive brown marmorated stink bug, Halyomorpha halys (Stål), in mid-Atlantic tree fruit orchards in the United States: Case studies of commercial management." Psyche: A Journal of Entomology 2012: 1-14.

Milnes JM, Wiman NG, Talamas EJ, Brunner JF, Hoelmer KA, Buffington ML, Beers EH. 2016. "Discovery of an exotic egg parasitoid of the brown marmorated stink bug, Halyomorpha halys (Stål) in the Pacific Northwest." Proceedings of the Entomological Society of Washington 118: 466-470.

Morrison WR, Lee D-H, Short BD, Khrimian A, Leskey TC. 2016. "Establishing the behavioral basis for an attractand-kill strategy to manage the invasive Halyomorpha halys in apple orchards." Journal of Pest Science 89: 81-96.

Ogburn EC, Bessin R, Dieckhoff C, Dobson R, Grieshop M, Hoelmer KA, Mathews C, Moore J, Nielsen AL, Poley K, Pote JM, Rogers M, Welty C, Walgenbach JF. 2016. "Natural enemy impact on eggs of the invasive brown marmorated stink bug, Halyomorpha halys (Stål) (Hemiptera: Pentatomidae), in organic agroecosystems: A regional assessment." Biological Control 101: 39-51.

Penca C, Hodges AC. 2018. "First report of brown marmorated stink bug (Hemiptera: Pentatomidae) reproduction and localized establishment in Florida." Florida Entomologist 101(4): 4p.

Talamas EJ, Herlihy M V., Dieckhoff C, Hoelmer KA, Buffington M, Bon MC, Weber DC. 2015. "Trissolcus japonicus (Ashmead) (Hymenoptera, Scelionidae) emerges in North America." Journal of Hymenoptera Research 43: 119-128.

Valentin RE, Nielsen AL, Wiman NG, Lee DH, Fonseca DM. 2017. "Global invasion network of the brown marmorated stink bug, Halyomorpha halys." Scientific Reports 7: 9866. 
Wermelinger B, Wyniger D, Forster B. 2008. "First records of an invasive bug in Europe: Halyomorpha halys Stål (Heteroptera: Pentatomidae), a new pest on woody ornamentals and fruit trees?" Bulletin de la Société Entomologique Suisse 81: $1-8$.

Yang ZQ, Yao YX, Qiu LF, Li ZX. 2009. “A new species of Trissolcus (Hymenoptera: Scelionidae) parasitizing eggs of Halyomorpha halys (Heteroptera: Pentatomidae) in China with comments on its biology." Annals of the Entomological Society of America 102: 39-47. 